\title{
REKENAAR-ONDERRIGPROGRAMME VIR LATYN VIR REGSTUDENTE: TEORIE EN PRAKTYK
}

Jo-Marie Claassen en Nadine Brand, Departement Latyn, Universiteit van Stellenbosch

\section{INLEIDENDE OPMERKINGS}

Sedert 1987 het die Departement Latyn, Universiteit Stellenbosch, hom toegele op die daarstel van rekenaarhulp vir Latynstudente. Tot einde 1994 was Latyn verplig vir regstudente, en hulle moes binne 'n jaar tot Matrikulasievlak gebring word, voordat hulle 'n volwaardige eerstejaarskursus, met beide regs- en klassieke tekste as basis, kon aandurf. Rekenaarhulp is gesien as ' $n$ middel om die basiese begeleide inoefening; waarvoor daar in so 'n vlugge kursus geen klastyd is nie, in studente se eie tyd aan hulle beskikbaar te stel. Daar is in die afgelope nege jaar deurgaans gepoog om rekenskap te gee oor wat bereik word. Die moontlikhede en toepassing van die rekenaar in die onderrig van Latynse letteren taalkunde is dus deurgrondelik ondersoek. Die studie het twee aspekte behels, evaluering van beskikbare programmatuur, en die opweeg van onderrigmoontlikhede aan die hand van studente-prestasie.

In die loop van verskeie besoeke aan Engeland en die VSA is die jongste tendense in RGOprogrammering nagevors.1 Gesprekke met RGO-taalonderrig-kenners het uitgewys dat RGO wél geskik is vir die onderrig, nie net van Latynse taalkunde nie, maar ook vir die verbeeldingryke toepassing van bv. "cloze-tegnieke" vir die lees van deurlopende tekste, en in die algemeen vir verrykende literatuurstudie. Daar is heelwat "kits-programme" in die mark wat hulle leen tot die invoeg van data in enige teikentaal.

Reeds in die eerste jaar van ondersoek het dit duidelik geblyk dat die meeste beskikbare Latyn-programmatuur vanweë drastiese verskille in onderrigfilosofie nie vir die praktiese onderrig in die lees van Latynse letterkunde aan hierdie Universiteit geskik is nie. Buitelandse Latynkenners se metodes van ontwikkeling en evaluering kon nie sonder meer in die Suid-Afrikaanse situasie toegepas word nie, maar moes tog ondersoek word om idees te ontgin vir die ontwikkeling van programmatuur. Die Dept. Latyn het van die Universiteit se Buro vir Voortgesette Onderwys gebruik gemaak vir die ontwikkeling en uitbouing van eie RGO materiaal. Die materiaal is departementeel ontwerp vir ontwikkeling deur BUVO se programmeerders. 2

Sedert die aanvang van rekenaarontwikkeling aan US, is studenteprestasie deurgaans gemonitor en ook sover moontlik vergelyk met die prestasie van diegene wat nie op die rekenaar gewerk het nie. Navorsing oor studente-prestasie in agt agtereenvolgende studie-

I Dank aan die Universiteit van Stellenbosch, verskeie instansies: die bestuur van die gewese Instituut vir Taalonderrig, en die Afdeling van Navorsingsonderrig vir finansiële steun, by verskeie geleenthede, en aan die Buro vir Universiteits- en Voortgesette onderrig, by name dr. M.M. Malan, vir praktiese steun met die ontwikkeling van eie materiaal.

2 Besondere dank aan kollegas, programmeerders en ander medewerkers, wie se name in die lys van sagteware by die US-produkte verskyn. 
siklusse het duidelik getoon dat rekenaarsteun (die plaaslik-ontwikkelde materiaal) LatynBeginnerstudente se prestasie in die lees van die teikentaal verhoog. Alle groepe studente wat van die Latyn-RGO gebruik maak, presteer beter as hul eweknieẽ in kontrolegroepe. Dit het egter telkens geblyk dat Latyn-RGO veral twee groepe, die mins begaafde en die mees begaafde studente, bevoordeel. Met die toetrede van studente uit tradisioneel minder goed toegeruste skole het die RGO ook 'n bydrae gelewer as waardevolle ondersteuningshulpmiddel. Wat volg is 'n beskrywing van bevindinge op die verskeie vlakke hierbo gemeld.

\section{Algemene tendense in RGO-programmering}

'n Rekenaar is nie slegs 'n elektroniese boek nie. Stap-vir-stap progressie, waar geen "bladsye oorgeslaan" kan word nie, is miskien tog sy mees onderskeidende kenmerk. Sy dinamiese, interaktiewe aard moet egter doelbewus ten volle benut word in die ontwikkeling van RGO-materiaal, en die student moet tot denke geprikkel word. Met hierdie kriteria in gedagte, is daar drie wyses waarop die ontwikkeling van RGO-materiaal aangepak kan word, naamlik:

(i) Eenvoudige, geoutomatiseerde programmetjies wat datalêers vol lees- of leerstof op die een of ander wyse vir die gebruikers gedeeltelik verskuil hou, hul daag om die versweë materiaal in te tik en hul dan in staat stel om hul antwoorde met die "korrekte" te vergelyk;

(ii) Doelmatige "met die hand geskrewe" programmatuur wat die studente stapsgewys sekere begrippe aanleer en die geleentheid bied om nuutverworwe kennis op die een of ander wyse te manipuleer;

(iii) Programmatuur wat vooraf ingewerkte materiaal d.m.v. sg. "Kunsmatige intelligensie" (hierna KI) self manipuleer en die studente dan daag om dit op die een of ander wyse te verwerk, en wat doelmatige terugvoer oor prestasie bied.

Tipe (i) het die voordeel dat die basiese program baie maklik deur 'n programmeerder ontwikkel kan word en die data daarna deur 'n Latynse vakkundige, of selfs 'n tikster, aangevul kan word. Tipe (ii) verg baie meer gespesialiseerde deurlopende programmering deur 'n programmeringskundige, maar dit het die voordeel dat dit 'n bepaalde literere aspek presies kan uitlig en vir die student bevatlik kan maak. Nie-verbale eienskappe van die rekenaar, bv. kleurverandering, kan aspekte van 'n student se intelligente leesvermoë verskerp. Die materiaal wat aan US ontwikkel is, voldoen aan die beskrywing van eersgenoemde twee kategorieë.

\section{Kunsmatige intelligensie: die stand van ontwikkeling}

Die derde tipe programmatuur, wat van KI gebruik maak, het die grootse deel uitgemaak van die buitelandse programmatuur wat in die VSA en Engeland ondersoek is. Dit het die voordeel dat dit, hoewel die aanvanklike programmering groot vaardigheid (en ook fyn analitiese denke in die teikentaal) verg, 'n beperkte hoeveelheid ingetikte data byna onbeperk kan verwerk, sodat dit in werklikheid baie ekonomies is t.o.v. die verhouding tussen programmeringstyd en studente-RGO-tyd. Dit het egter die nadeel dat dit, in sy eenvoudigste toepassings, uiters vervelige oefeninge kan oplewer, en ook foutiewe vorme kan genereer (bv. in die geval van onreëlmatige Latynse woorde) of dat dit onsinnige vertalings kan oplewer (bv. in vertalingsoefeninge). 
Die moontlikheid om hierdie KI data as basis vir baie meer gesofistikeerde programme (wat enige Latynse teks, trouens, alle Latynse letterkunde, op verskillende vlakke vir 'n student bevatlik kan maak) te gebruik, word tans deur verskeie buitelandse kenners ontgin (Kerschenbaum, Culley). Na wat verneem word, het die outeurs van sodanige programme probleme ondervind met die omvang van data wat so 'n stelsel verg. Geeneen van hierdie gevorderde tipe programme is tot dusver voltooi of finaal gepubliseer nie.

\section{Hiperteksprogramme}

Die Hiperteks-tegniek word tans in die VSA op hierdie wyse aangewend. Dit kan ook op ander wyses ingespan word. By die Dept. Duits, US, word dit tans aangewend om letterkundige werke op verskillende vlakke vir studente bevatlik te maak. Die ontwerpers van die Griekse Perseus-Projek van die Universiteit Harvard gebruik die tegniek op soortgelyke wyse, met byvoeging van visuele materiaal, en daarby die aanname dat data wat tans in KI-modus ingevoer word, met verdere tegnologiese ontwikkeling nog ingespan sal kan word op wyses wat tans nog ondenkbaar is.

'n Aspek wat tans by die Dept. Latyn, US, aandag geniet, is die moontlikheid om veeltalige programmatuur te laat ontwikkel, waar studente op verskillende vlakke toeligtende hulp in hul eie taal sal kan oproep. Hiervoor is reeds begin met die teoretiese ondersoek van raakpunte en verskille tussen Latyn en die Swart tale. Hierdie navorsing sal kan dien as riglyn vir die ontwikkeling van byvoegings tot die Dept. Latyn se bestaande materiaal.

\section{BESKIKBARE BUITELANDSE PROGRAMMATUUR}

Daar is baie materiaal, waarvan min geskik is. Die programmatuur wat hier bespreek word, is in die een of ander opsig navolgingswaardig.

\section{Universiteit Cambridge}

Van die eenvoudigste programmetjies beskikbaar is die wat geskep is as begeleiding van die bekende "Cambridge Latin Course", wat egter meer geskik is vir skoolgebruik. Oefeninge sluit in herkenning van naamvalle, lees-met-begrip, bv. ordening van Latynse sinne om 'n."storie" te maak, woordeskat en 'n "avontuur" spel, wat 'n verbeeldingryke kombinasie van toets- en leergeleenthede bied. Die vindingrykheid en verskeidenheid van die CLC rekenaarprogramme is navolgenswaardig. Teikenleerlinge vir die programmatuur is 12- en 13-jariges.

\section{Universiteit Leeds: "Learning Latin"}

Teenoor Cambridge se "spel" benadering, wat baie programmeringstyd in beslag neem, roem die vervaardigers van die Leeds "Learning Latin Support Group" hulle daarop dat die rekenaartaal LISP ("Listing Production") baie ekonomies wat betref programmeringstyd is omdat dieselfde stel data (wat as "lyste" ingevoer word), vir 'n verskeidenheid doeleindes opgeroep kan word, en baie ure rekenaaroefening aan 'n enkele student kan bied. Dit bied 'n "les-modus", waarin 'n bepaalde "les" uit die handboek van John Randall, "Learning Latin" (Liverpool 1986), getoets word, en 'n "hersieningsmodus" wat dan alle werk tot op 'n bepaalde lesvlak toets. Toetsing behels dat die student gedwing word om analities na te 
dink oor elke woord in ' $n$ Latynse sin in die orde waarin dit voorkom. Die waarde daarvan is dat studente leer om, met hul verworwe kennis, woorde in Latynse sinne opeenvolgend te lees. Die program het egter nog nie 'n module waarin die koper sy eie data (Latynse sinne) kan inwerk nie.

Die program word voortdurend opgradeer, o.a. deur gebruikmaking van kleur, maar onses insiens word die kleur nie werklik sinvol benut nie. Dit mag miskien afwisseling bied, maar help byvoorbeeld nie mee om die student se regterbrein (of "kreatiewe sy") aktief te betrek nie. Besonder waardevol is egter dat elke student self die tipe, vlak en "modus" van oefening kan kies en 'n gedetailleerde analise van sy vaardigheid aan die einde van elke sin ontvang (Vgl. Claassen 1991).

\section{Brooklyn College, New York, NY}

Hier word 'n tweeledige doel met programmatuur-ontwerp nagestreef: 'n opvoedkundige drilprogram, genaamd SCIO, berus op 'n KI-basis, wat die outeurs so ontwerp het dat dit kan lei tot 'n gesofistikeerde analiseprogram waarmee die tipiese sinsbou van 'n bepaalde Latynse outeur (bv. Cicero) uitgelig en gekodifiseer kan word. Hierdie analise sou kon dien as middel tot deskriptiewe literêre analise (vir gevorderde navorsing oor 'n outeur), maar ook die bevatlik-maak van Latynse tekste vir die beginnerstudent. Die SCIOprogram, soos dit tans by Brooklyn College benut word, vervul dus 'n nuttige RGO-rol, maar sy huidige formaat het gebreke inherent aan KI-programme.

Interessant is verder die feit dat die Brooklyn College sy eie toelatingseksamen vir voornemende studente bedryf. Diegene wat die toets in die lees en/of skryf van Engels nie slaag nie (hetsy immigrante, Spaanssprekendes, of studente uit 'n minderbevoorregte omgewing), word verplig om een kursus uit 'n verskeidenheid van remediërende kursusse te kies. Die Latyn-opsie bestaan uit 'n formele taalkursus wat teen 'n stadige tempo aangebied word. Die kursus is ontwerp na aanleiding van suksesvolle remediërende Latynkursusse vir laerskoolleerlinge in minderbevoorregte gebiede. Hierdie opsie het volgens die aanbieders jaarliks 'n suksessyfer van $88 \%$ teenoor die ongeveer $12 \%$ sukses van ander remediërende kursusse. Hierdie studente maak ook van die RGO-program gebruik. Hul sukses is deels aan die bewese taalverrykende eienskappe van Latyn te danke, en deels aan die ondersteunende verryking van die RGO.

\section{Universiteit van Delaware, Newark DE: Aangepaste Hiperteks}

Prof Gerald Culley van die Universiteit Delaware is die voorste Amerikaanse kenner van die toepassing van RGO op Latyn. Daar het reeds ' $n$ hele reeks materiaal onder sy aanvoering verskyn. Culley werk tans aan 'n hiperteks-sisteem ("Liber") om enige Latynse passasie vir die onervare leser bevatlik te maak. Met 'n beperkte woordelys van ongeveer 1500 woorde en die gebruik van gevorderde KI-tegnieke kan die hoeveelheid data wat benodig word vir die hiperteks-annotering van bv. ongeveer vier Cicero-toesprake, binne hanteerbare perke gehou word.

Met Culley se $\mathrm{KI}$-programme as basis, is 'n Latynse avontuurspel ontwikkel. Die spel word in Latyn as voertaal bedryf, en bied die speler 'n beperkte maar voldoende woordeskat waaruit sinne vryelik gegenereer kan word. Dit is gebaseer op die geskiedenis van die Germaanse opstande teen Romeinse gesag in 9 n.C. Dit werk soos 'n tipiese "vertakte verhaal" maar het die didaktiese voordeel dat enige foutiewe Latyn wat deur die speler ingetik word, deur die KI getoets word aan die hand van sy naaste korrekte ekwivalent, wat vir die speler se goedkeuring voorgehou word. Die didaktiese filosofie van 
die spel is dat 'n student wat as't ware in die teikentaal moet "dink" en wat dit self manipuleer, onder "toesig" van 'n KI, op die nie-bewuste kognitiewe vlak met die taal as 'n lewende entiteit omgaan. Dit sal as versterking dien vir die intelligente lees van enige ander literêre teks.

\section{US SE EIE PROGRAMMATUUR}

Min van die Latyn-RGO programmatuur wat in die VSA en Engeland beskikbaar is, is op dieselfde hoẽ vlak as die Delaware-materiaal en min is toepasbaar in die Suid-Afrikaanse didaktiese opset. Einde 1986 is daar reeds by Stellenbosch met die ontwerp van eie materiaal begin. Daar is op twee tipes programmatuur besluit:

(i) 'n baie eenvoudige, willekeur-bedryfde toets-leer program, genaamd CONSENSUS (omdat dit afhang van ooreenkomste tussen die teks en wat die student intik);

(ii) 'n spesiaal-ontwerpte program wat studente stap vir stap deur basiese sinstruktuurbeginsels neem, met kleurverandering as terugvoermeganisme, genaamd PISCINA (met 'n onderafdeling STRUCTURAE).

\section{Willekeur-bedryfde toets-leer programme}

CONSENSUS behels 'n stel van vier programme wat ontwikkel is vir onderrig in en oefening van Latynse taal en woordeskat. Die reeks van vier willekeur-programme (randomizing programs) werk op die beginsel van ooreenkoms tussen wat die studente invoer en wat die rekenaar geprogrammeer is om te "weet." Hoewel die programme in "toetsformaat" voorberei is, is hul hoofdoel onderrig deur middel van studente se dinamiese interaksie met die rekenaar. Hierdie oefeninge is nie gemik op vervanging van gewone klas-toetse of eksamens nie. Klem word op die aspek van "spel" geplaas, en studente word aangemoedig om met hulself te kompeteer. Telkens as 'n sessie afgesluit word, is daar ' $n$ meganisme binne CONSENSUS wat die datum, tyd, student se naam, tipe oefening gedoen, tyd aan ' $n$ oefening bestee, telling behaal en moontlike telling, aanteken. Die dosent kan studente se RGO-tyd oor die verloop van 'n kwartaal of termyn nagaan.

Elke program het 'n beperkte doel. Almal berus op variante van die basiese eienskappe van student-rekenaar interaksie, soos byvoorbeeld die moontlikheid om deur willekeurige oproep dieselfde oefening onbeperk te kan herhaal, en beperkte terugvoer oor korrekte en verkeerde antwoorde. Totale tyd deur elke student bestee, asook hul prestasie, word aangeteken, wat dit vir studente moontlik maak om op hul eie vorige prestasies te verbeter.

Al die oefeninge, of lesse, bestaan uit 'n "dop", wat dataleers met oefeninge oproep. Die dop self bevat geen data nie. Dit stel net vrae en hou telling. Studente se telling word in 'n loglêer gebêre. Elke stel lesse het of 'n spyskaart, of instruksies om die lesse in volgorde op te roep. Die "dop" maak dit moontlik vir onderwysers of dosente met geen ervaring van programering om self data vir leerlinge of studente voor te berei. US bemark reeds 'n spesiaal-aangepaste variant, 'n sg. "outeursmodus" van die "dop", vir gebruik deur ander. Hierdie rekenaarpakket stel enige dosent wat 'n betrokke onderrigprogram aankoop, in staat om sy eie stof in die program in te voer. Omdat Latynonderrig op 'n hele verskeidenheid didaktiese filosofië berus, en omdat daar so 'n verskeidenheid Latynhandboeke en -onderrigmetodes in die RSA beskikbaar is, is hierdie outeurspakkette onontbeerlik. 
CONSENSUS is oorspronklik ontwerp vir gebruik deur Afrikaanssprekende studente, maar 'n groot deel daarvan is nou drietalig (Afrikaans-Engels-Latyn). In sekere gevalle kan programme volledig in Engels gespeel word. Aanvullings (ook in Xhosa) word steeds bygewerk, en data kan in enige ander taal bygevoeg word, 'n belangrike oorweging in die Suid-Afrikaanse elf-talige opset. Die programme is in 'n eenvoudige vorm van die rekenaartaal Turbo-Pascal geskryf en heeltemal onbuigsaam, sodat geen variant van wat in die dataleers ingetik is, aanvaar word nie. Hierdie moontlike nadeel word 'n voordeel as studente bewus word van die noodsaaklikheid dat hulle presies en absoluut akkuraat moet werk. Selfs as die "spasiebalk" per abuis getik word, sal die program dit as "n "fout" registreer.

In al hierdie programme is die doel om die dinamiek van die rekenaar in te span om "driloefening" in "uitdaging" te verander, nie om onbekende werk te onderrig of oorbekende werk te toets nie. Elke raam wat op die skerm verskyn, bied studente meer materiaal om te leer as wat "getoets" word en hulle kom gou agter dat hulle meer kry as wat hulle moet gee. Verder wys die toetsaspek ook leemtes in hul kennis uit, nl. watter werk meer aandag nodig het. Hulle word ook nie toegelaat om foute voort te sit of onbeholpe aan te ploeter nie: na drie probeerslae gee die masjien die korrekte terugvoer, wat dan vergelyk kan word met hul eie pogings, wat op die skerm bly, met duidelike aanduiding daarby dat dit verkeerd is. Terugvoer word in rooi verhelder, 'n doelbewuste funksionele gebruikmaking van kleur, gemik daarop om ook die regterbrein by die leerproses te betrek (vgl. Claassen 1991).

Omdat die skerm in elk van die vier programme anders vertoon, is daar genoeg variasie om studente se aandag te behou. Verveling is ' $n$ groot probleem in Latyn RGO. Die willekeurige uitlaat van elemente verskil met elke herspeel, wat 'n byna eindelose stel oefeninge vir gebruik en hergebruik bied.

Twee van die CONSENSUS programme werk presies dieselfde:

(i) VERBA is 'n woordeskat-oefening gegrond op Lexis Latina (Van Stekelenburg et $a l$., Pretoria, 1985) wat willekeurig een van die woordeboekbesonderhede of die betekenis van 'n woord uitlaat. Enigeen van verskeie sinonieme in Afrikaans of Engels word aanvaar. Dataleers is alfabeties, een vir elke letter van die alfabet. Studente mag dieselfde oefening telkens herhaal totdat hulle die werk volkome beheers. Die dop is aangepas om dataleers te aanvaar, wat 'n dosent na gelang van behoefte self kan saamstel. Elke datalêer kan tot ongeveer 50 Latynse woorde met hul besonderhede en betekenisse bevat.

(ii) ARS GRAMMATICA oefen studente se beheer oor verbuigingstabelle. Dit laat ook willekeurig een van die besonderhede uit. Die meeste items beslaan tot drie woorde per reël (bv. naamval, s.nw, b.nw). Die program verskaf self 'n indeks van beskikbare tipes paradigmata.

(iii) FORMAE is 'n veelkeuse-taaloefening, wat op die beginsel van herkenning van die Latynse morfologie berus. Studente moet een item uit 'n stel van vyf kies om te pas by ' $n$ bepaalde definisie. $\mathrm{Na}$ ' $\mathrm{n}$ foutiewe respons word ' $\mathrm{n}$ ontleding van die betrokke afleier in 'n kontrasterende kleur aangebied. As die student korrek antwoord, of na die derde foutiewe respons, word die vier afleiers se ontleding gegee, tesame met die ontleding van die regte antwoord, wat in rooi verhelder word. Weer is eie programmering moontlik.

(iv) Die laaste van die reeks, ARS SCRIBENDI, werk op die sg. "cloze"-beginsel, gebaseer op woorduitgange. Die laaste twee letters van 'n teks word willekeurig uitgelaat en moet deur studente ingevul word. Hierdeur kry hulle 'n begrip van die 
belangrikheid van woorduitgange. Studente verstaan 'n sin se struktuur as hulle die woorduitgange korrek kan voltooi. Die program werk veral goed as die data by herhaling sinne met dieselfde struktuur toon. Studente kan uit waarneming van sinne waar geen uitgange weggelaat word nie, ontbrekende uitgange aflei. Hierdie spel is makliker vir studente as om in Latyn te probeer skryf (die sg. "prose composition" van vorige eras).

"Verkeerde" antwoorde word nie by die student ingeskerp nie. As 'n verkeerde letter ingetik word, ignoreer die masjien dit. $\mathrm{Na}$ die derde fout, word die antwoord in flitsende rooi letters gegee. Die teoretiese onderbou van hierdie program verskil van die voorafgaande, en le op 'n hoër kognitiewe vlak. Willekeurige uitlaat van uitgange vereis dinamiese interaksie tussen student en teks. Studente meen dat hulle op uitgange konsentreer, maar in werklikheid gaan hulle met die teks as geheel om. Dit wys ook die basiese verskil tussen Latyn en hulle moedertaal uit: vir sprekers van Afrikatale, dat uitgang en nie voorvoegsels nie, betekenis bepaal, en vir Afrikaans- en Engelssprekendes, dat uitgang belangriker is as woordorde. Herkenning van watter uitgang in 'n bepaalde sin vereis word, toon dat die student werklik die struktuur van 'n sin verstaan, omdat uitgang woordfunksie in 'n sin aandui. Selfs as 'n tweeletter voegwoord oopgelaat word, sal grondige kennis geverg word om te weet of neweskikkende "et" of onderskikkende "ut" ontbreek, so ook in die geval van bv. voorsetsel "ex" of sy teendeel "ad".

Die tegniek waarin studente 'n gedeeltelik-versweë teks moet aanvul (sg. "clozetechnique"), kom in baie moderne Latyn-onderrigtekste voor. Die rekenaar vergemaklik die proses en gee vir die studente onmiddellike terugvoer, terwyl dit hulle ook afrig in stilisties bevredigende Latyn.

Tans is die volgende beskikbaar: gegradeerde, maar deurgaans eenvoudige stories uit die Vulgaat-Nuwe Testament ("Sic Venimus Romam"), Nepos se "Vita Hannibalis" (Stellenbosch, Tria Saecula-reeks, 1994), Regslatyn-tekste uit "De Iure" deur AV van Stekelenburg, (Pretoria, 1991) en die vereenvoudigde Petronius-uitgawe, "Millionaire's Dinner Party" van M.G. Balme (Oxford, 1973). Dosente kan leesstukke uit hul studente se eie handboeke ook in die formaat verwerk.

\section{Sinstrukture}

Die ander rekenaar-onderrig modus bied meer formele ontleding en sintese van sinstrukture, weer die moontlikheid van onmiddellike terugvoer, asook die moontlikheid om deur kleurverandering op nie-verbale wyse inligting deur te gee, en daardeur 'n ander breinarea te betrek. Gebruik van kleurkryt om sinsdele te onderskei is 'n ou taalonderrigtegniek. Die rekenaar stel studente in staat om self hierdie tegniek te beheer, wat versterking van inligting ook op die intuïtiewe vlak vaslê.

Daar is twee stelle spesiaal-ontwerpte oefeninge, genaamd PISCINA en STRUCTURAE. Eersgenoemde is gerig op herkenning van die deurslaggewende invloed van 'n Latynse werkwoord op die struktuur van 'n Latynse sin. Dit rig studente af deur middel van veelkeusevrae om die basiese struktuur van 'n modelsin te herken. Daarna moet hulle soortgelyke strukture in 'n "poel" van sinne (soms 'n storie, soms losstaande sinne, maar met verskillende basiese strukture) merk. As 'n sin korrek geïdentifiseer word, verander die kleur van die betrokke sin na dié van die modelsin, en die student gaan voort. Hierna word ' $n$ tweede modelsin gegee en die student moet op soortgelyke wyse sy struktuur identifiseer, en dan sy "maats" in die "poel" soek. Nou kom 'n ander kleur op die skerm. As die hele "poel" korrek in sy komponente ontleed is, verskyn dit in reënboogformaat, 
met onderaan die volle spektrum van modelsinne, elk in sy eie kleur. Kleurkontras onderstreep visueel wat die student kognitief moes uitredeneer.

STRUCTURAE maak gebruik van dieselfde tegnieke, maar sy teiken is inskerping van uitbouings van die selfstandige naamwoord (byvoeglike naamwoorde en bysinne, besitvorme en deelwoorde met hul bywoordelike en ander uitbreidings). Die Latynse deelwoord is, net soos die werkwoord waarvan dit afgelei word, 'n belangrike groeipunt in enige sin, met sy veelvuldigheid van verskillende vorme en funksies. Latyn het byvoorbeeld ook 'n toekomende deelwoord, wat tradisioneel 'n groot struikelblok vir studente is. Kleurverandering word weer ingespan om strukturele ooreenkomste uit te wys. Alle woorde wat uitbreidings op 'n bepaalde naamwoord is, kry dieselfde kleur as die naamwoord. Terselfdertyd word die frases of bysinne wat so gevorm word, opeenvolgend onderaan die skerm getoon, met 'n kontekstueel-geskikte vertaling daarby.

Hier is inhoud en proses as integrerende eenhede geprogrammeer, dus kan hierdie programme nie as "dop" vir dosente of onderwysers se eie tekste dien nie. Sekere van die programme is reeds in Engels vertaal en kan moontlik uiteindelik deur middel van 'n hiperteks-modus ook in verskeie van die ander landstale aangebied word. Studente moet die Latynse sinstrukture verstaan as ooreenkomstig of kontrasterend met die strukture van hul moedertaal.

\section{PRESTASIE VAN LATYNBEGINNERS WAT IN 1991-1994}

\section{OP DIE REKENAAR GEWERK HET}

Ondervinding het getoon dat totale tyd voor die rekenaar bestee die belangrikste faktor in die effektiewe benutting van rekenaargesteunde onderrig is. Studente word aangemoedig om soveel moontlik tyd op te bou. Sedert 199.1 is gepoog om studente te verplig om 'n minimum van 30 minute per week aan RGO te bestee deur 'n punt van 5 hiervoor by hul klaspunt in te werk. Die basiese premis, afgelei van navorsing en ondervinding in die vorige vier jaar, was dat die ideale en mees geslaagde werkwyse gereelde, weeklikse werksessies behels. Studente het nie ewe konsekwent gewerk nie. Sommiges het meer as die voorgeskrewe tyd gewerk, baie minder. Ten spyte van verpligting het nie alle studente van hierdie gerief gebruik gemaak nie. So was dit dan moontlik om uit dieselfde klas 'n kontrolegroep te isoleer.

Die jaar 1991 was seker 'n numeriese hoogtepunt, toe 480 eerstejaars vir Latyn Beginners ingeskryf het. Teen Junie het heelwat uitgesak en aan 313 is daar uiteindelik ' $n$ finale punt toegeken. Hiervan toon ons rekords dat 141 glad nie op die rekenaar gaan werk het nie, en slegs 43 het die vereiste totale tyd ingesit, of selfs meer. Vir almal is, volgens 'n formule (gebaseer om beide lengte en gereeldheid van werksessies) 'n syfer tussen 0 en 5 by hul jaarpunt gereken. ${ }^{3}$ Die verskil tussen gemiddelde prestasies van studente wat glad nie gewerk het, en die wat meer en langer as die vereiste minimum gewerk het, was $11,5 \%$, en, waar meer as $28 \%$ van die eerste groep gesak het, het geeneen van die "harder" werkers gesak nie. Tabel 1 bevestig dat gereelde rekenaarwerk, van minstens 30 minute per week, oor die hele semester versprei, die beste resultate vir 'n student oplewer.

3 Om studente aan te moedig om gereeld te werk, en om die $5 \%$ beloning aan die mees doeltreffende studente te gee, is (beide in Junie en November) die totale minute wat deur 'n student gewerk is, vermenigvuldig met die aantal weke (maksimum 13) waarin 'n student gaan werk het $\{(13 \times 30) \times 13=5070\}$ en dit is deur 1000 gedeel, om 'n syfer uit 5 te verwerf. 
Tabel 1: Prestasie van verskillende groepe volgens tyd gewerk

\begin{tabular}{|l|r|r|r|r|r|r|}
\hline Syferwaarde (= tyd gewerk) & 0 & 1 & 2 & 3 & 4 & 5 \\
\hline & & & & & & \\
Finale punt gemiddeld & 52,5 & 52,6 & 54,8 & 56,8 & 60,4 & 60,7 \\
\% wat sak & 28,4 & 28,8 & 21,2 & 15,7 & 22,2 & 6,9 \\
\% wat bo 75\% kry & 4,2 & 10,0 & 9,0 & 15,7 & 16,7 & 13,9 \\
\hline
\end{tabular}

Van die studente wat baie meer as die vereiste tyd ingesit het, is 'n verdere ontleding gedoen. Hulle het in November 'n gemiddeld van $64,0 \%$ behaal, geeneen van hulle het gesak nie, en $17,4 \%$ het cum laude geslaag. Gemiddelde prestasie het in alle gevalle tred gehou met gereeldheid van toewyding.

In 1992 is naastenby dieselfe patroon ondervind. In 1993 was daar heelwat minder studente ingeskryf, en minder het enduit die volle tyd voor die rekenaar ingesit. Die 14 wat wel die verwagte tyd of meer ingesit het (ongeveer 6\% van die klas), het 'n eksamengemiddeld van net onder die $70 \%$ behaal. Twee het byna volpunte behaal. Van die res het geen een minder as $60 \%$ behaal nie. Die kontrole-klasgemiddeld (nie-werkers) was ongeveer $45 \%$.

\section{STUDENTE-RESPONS IN 1993 EN 1994}

Die CONSENSUS-programme is sedert 1992 aan die Universiteit van Wes-Kaapland verhuur, en is aangepas vir hulle Latynkursus. Anekdotale getuienis is dat veral Swart studente wat van die gerief gebruik gemaak het, besonder goed gevaar het en hulle klasmaats gaandeweg verbygesteek het. 'n Vraelys wat deur kollegas by UWK ontwerp en toegepas is, het heelwat positiewe kommentaar opgelewer. Hierdie vraelys is deur skrywers aangepas en einde 1993 en 1994 aan die hele Latyn Beginnersklas aan US uitgedeel. Tabel 2 behels 'n skematiese uitensetting van die 1993 responsbasis vir die ontleding. Die aantal studente in 1994 was kleiner, maar die verspreiding is vergelykbaar.

\section{Tabel 2: Evaluasie van Consensus en Piscina: Deelnemerprofiel}

\begin{tabular}{|l|r|}
\hline Geregistreerde studente in hele klas & 230 \\
Hoeveelheid vorms ontvang en verwerk & 201 \\
Onbeantwoord & 29 \\
Afrikaans as huistaal & 151 \\
Engels as huistaal & 37 \\
Ander (Tweetalig AE, Duits, Portugees, Pools) & 13 \\
\hline
\end{tabular}

Studente is eerstens gevra om aan te dui watter punt hulle verwag. Sodanige inligting is altyd nodig om die studentemenings wat verder geopper word, te temper. Eerstens is studente gewoonlik realisties oor hul verwagtinge, en tweedens kan 'n groter waarde geheg word aan die positiewe oordeel van 'n suksesvolle student. Onsuksesvolle studente se menings is om 'n ander rede belangrik. Van hulle kan 'n mens leer wat 'n sukkelende 
student se behoeftes is. Dit is baie interessant om te let dat die response hier 'n "normaalkurwe" vorm. Opvallend was dat in beide jare veral lae presteerders geneig was om hul eie vermoëns te oorskat (sien fig. 1).
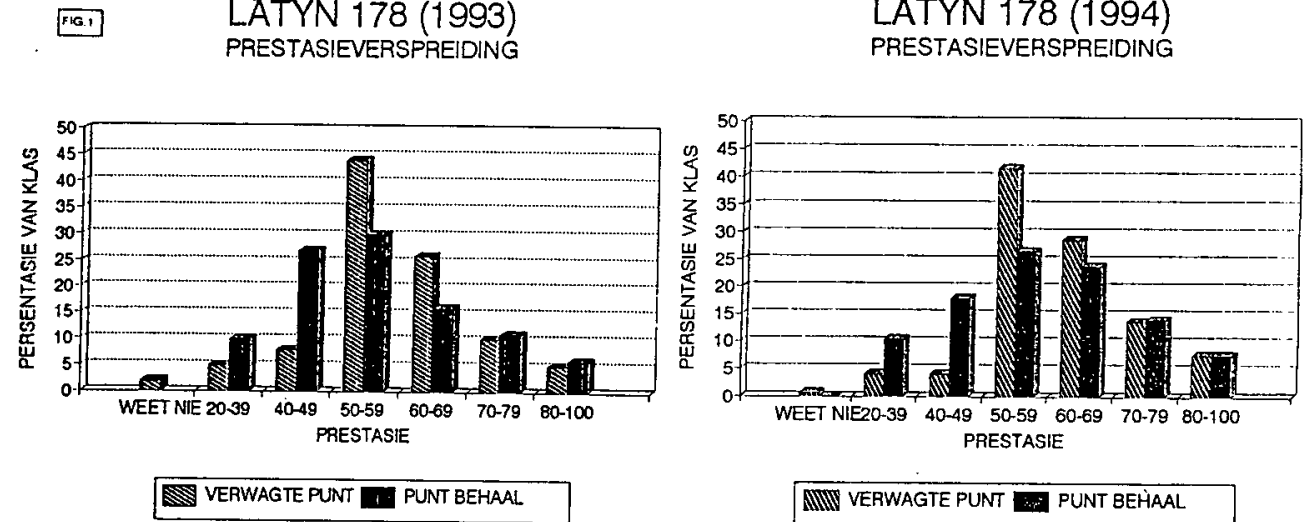

AW VERWAGTE PUNT BM PUNT BEHAAL

Figuur 2 toon dat slegs 'n klein groep in 1993 "dikwels" gewerk het. Anekdotale getuienis oor redes waarom die RGO "selde" gebruik is, is moeilik om te kategoriseer, maar gebrek aan tyd, of persoonlike redes, word as hoofsaak aangegee. 'n Beduidende groep beskryf hulself as "lui". Korrelasie tussen verwagte punt (Fig 1) en hoe dikwels gewerk, is nie, soos miskien te wagte sou wees, absoluut positief nie, hoofsaaklik miskien omdat sekere goeie studente nie die behoefte aan rekenaarsteun het nie. Sekere hoë presteerders meen dat selfstudie meer doeltreffend is. Ander vind dit "onnodig". Onderpresteerders is ongemotiveerd, het belang verloor en agter geraak, of getuig van onbeholpenheid. Oor die algemeen, egter, was die oordeel oor die beginsel van RGO ook by die meerderheid studente positief, selfs waar hulle nie gewerk het nie.
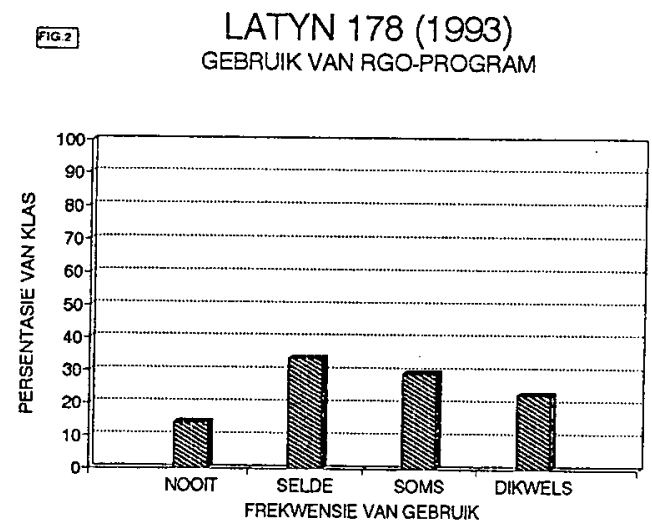

'n Vyfde vraag het vereis dat studente hulle voorkeure vir die verskillende oefeninge aandui. Uit Tabel 3, die respons van 1993, is dit duidelik dat die woordeskatoefeninge verreweg as die belangrikste beskou is. Dieselfde tendens is in 1994 bespeur. 
Tabel 3: Orde van voorkeur van programme soos deur

respondente aangegee

\begin{tabular}{|l|r|r|r|r|r|r|}
\hline $\begin{array}{c}\text { Voorkeure in programgebruik } \\
\text { (getal studente per keuse) }\end{array}$ & 1 & 2 & 3 & 4 & 5 & $\begin{array}{l}\text { gemid- } \\
\text { deld } \\
\text { (rel. } \\
\text { gewig) }\end{array}$ \\
\hline & 160 & 9 & 2 & 4 & 10 & 172 \\
Verba (Woordeskat) & 22 & 50 & 29 & 20 & 5 & 88 \\
Formae (Grammatika) & 11 & 13 & 22 & 36 & 35 & 56 \\
Ars Gram. (Paradigmata) & 14 & 28 & 29 & 27 & 24 & 69 \\
Ars Scribendi (Woorduitgange) \\
Piscina \& Structurae (Struktuurleer) & 17 & 18 & 24 & 23 & 37 & 62 \\
& & & & & & \\
\hline
\end{tabular}

Vraag 6 was "Hoeveel nut reken u het die RGO vir u toetsprestasie ingehou?" In beide jare het bykans die helfde dit as "taamlik nuttig" bestempel, wat telkens meer is as die kleiner persentasie wat "net soms" gewerk het. 'n Mens moet aflei dat selfs van diegene wat ongereeld van die gerief gebruik gemaak het, tog wel waarde daaraan geheg het.

Vraag 7, op watter gebied (Woordeskat, Grammatika of Vertaling) studente verbetering na gebruik van RGO ondervind het, het in beide jare 'n merkwaardige ooreenkoms tussen studentevoorkeure soos by vraag 5 aangedui, en die aard van die verbetering wat studente in hul prestasie bespeur het, ontlok. Hoewel nie een van die RGO programme op vertalingstegnieke toegespits word nie, het ongeveer $13 \%$ van die studente tog verbetering in vertalingsvermoẽ aangedui. Dit is 'n indikasie dat die hiërargie van vermoëns wat as teiken deur die programontwerpers gestel word, wel bereik is.

Vraag 8 het vrye kommentaar en kritiek van studente uitgelok. Weer is tendense duidelik. In beide 1993 en 1994 het slegs enkele van die studente wat "nooit" die programme gebruik het nie, kommentaar of kritiek gelewer, maar van hulle het verskeie tog gemeen dat dit verpligtend moet wees. Miskien te verwagte was dat die kommentaar en kritiek van studente wat "dikwels" en "soms" die programme gebruik het, hoofsaaklik positief of baie positief was. Toppresteerders (met verwagting van 80 - 100\%) meen telkens dat dit nuttig en doeltreffend is, maar onnodig vir hulle. Nie-presteerders is meesal baie eerlik in hul respons, en la merendeels die blaam vir nie-sukses voor hul eie deur. Negatiewe kommentaar is ook gelewer op rekenaars as sulks, maar hierdie studente kon miskien eerder die fout by hulself as by die sisteem gevind het.

Hierdie studie het vir die programontwerpers finaal oortuig dat die sisteem sy plek volstaan in die suksesvolle voorbereiding van Latyn Beginnerstudente, maar studente se kritiek op die sisteem van implementering is tog ook ernstig opgeneem.

\section{VERGELYKING TUSSEN DIE PRESTASIE VAN 1993 EN 1994}

$\mathrm{Na}$ aanleiding van die kommentaar in 1993 ontvang, is in 1994 (die laaste jaar waarin vakplig vir Regstudente gegeld het) 'n alternatiewe sisteem van "dwang" gebruik. Tyd voor die rekenaar bestee is weekliks versyfer en as ' $n$ bonus by die totaal van klastoetse gevoeg. In wese het dit geen verskil aan die klassyfer gemaak nie, maar aangesien die 
"beloning" vir rekenaarwerk meer onmiddelik sigbaar was, het studente baie meer geredelik enduit aan die rekenaarsisteem deelgeneem, soos afgelei kan word van Figuur 3.

3
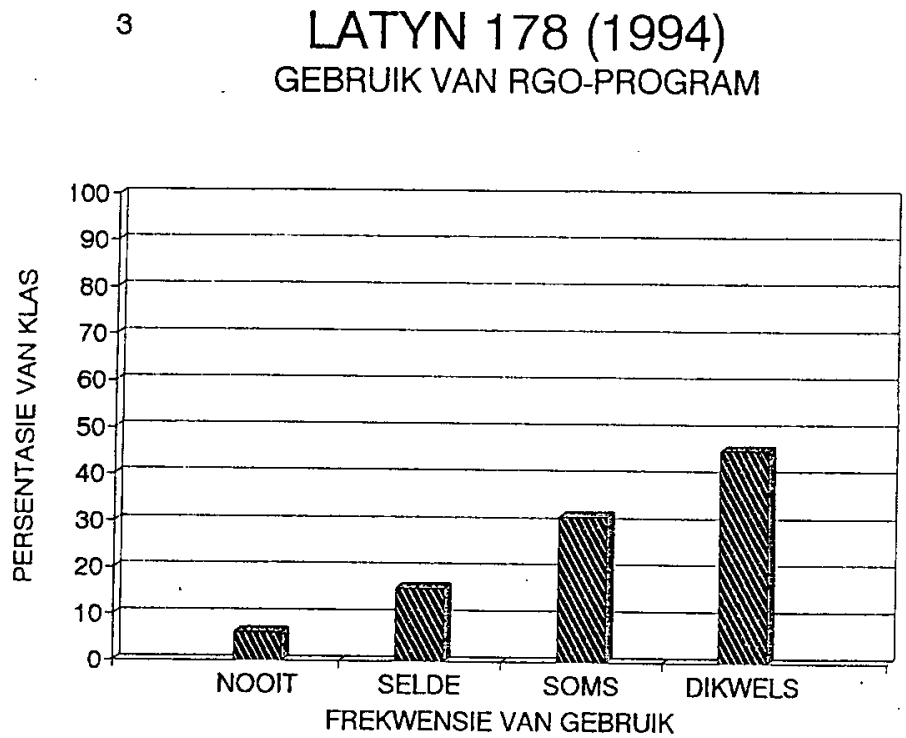

Dat daar 'n sterk korrelasie tussen studente-prestasie en RGO-bedrywighede is, kan afgelei word deur die twee jare te vergelyk. In 1994 het meer studente enduit gewerk, en van hulle het weekliks meer tyd voor die rekenaar deurgebring. Figuur (4) toon die verhoogde prestasie so duidelik dat geen verdere bespreking nodig is nie.

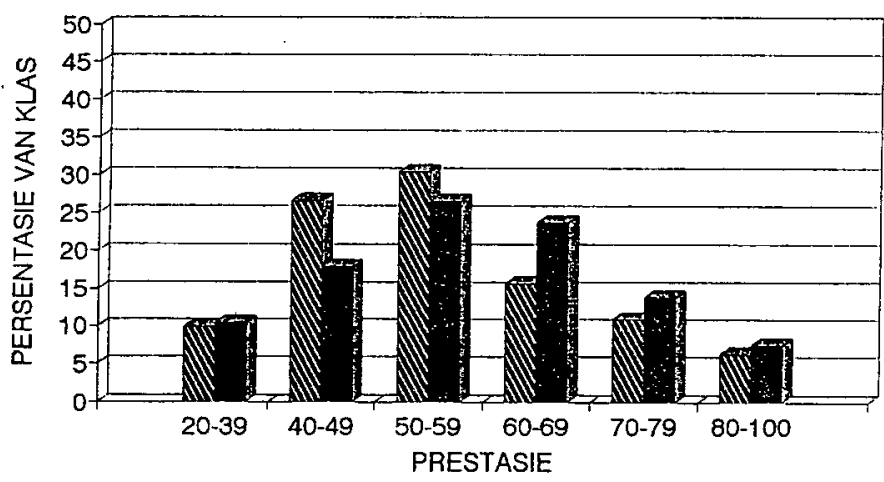

MIII 1993 1994 
Die jaar 1994 het egter die einde van 'n era ingelui. Latynse vakplig, wat sedert 1965 statuter afgedwing is, is beëindig. Die studie van Latyn is nou vrywillig. Uiteraard is die getal inskrywings vir Latyn Beginners in 1995 landswyd (maar veral aan US, waar die administratiewe organisasie van 'n nuwe bedeling toevallige, tegniese probleme opgelewer het) heelwat kleiner. Ook is, om verskeie redes, oorgegaan na 'n alternatiewe onderrigteks (Oxford Latin Course van M Balme en J. Morwood, Oxford, 1987), waarvoor daar inderhaas slegs woordeskat en "Cloze"-oefeninge ontwikkel kon word. Om die probleem van die frustrasie van 'n goeie student wat nie werklik die oefeninge nodig het nie, die hoof te bied, is daar begin met 'n glyskaal sisteem: na gelang van studente se prestasie in ' $n$ bepaalde week word daar meer of minder tydplig aan indiwiduele studente voorgeskryf. Hierdie studente het so pas hul eerste eksamen afgelé. Weer kan die menslike faktor nie buite rekening gelaat word nie: dit is juis die twee toppresteerders, wat dit nie nodig het nie, wat wel die meeste tyd ingesit het, en, soos verwag kan word, dus des te beter presteer het. Die twee swakstes het, binne hierdie vrywillige sisteem, hul vrye keuse uitgeoefen om nie aan die RGO-sisteem deel te neem nie, met voorspelbaar rampspoedige gevolge.

Die uitdaging is dus nog daar: om alle ingeskrewe studente te oortuig van die baie duidelik positiewe invloed wat RGO op hul prestasie kan he. Waar Suid-Afrikaanse klassici in die verlede die luukse kon geniet van kwantiteit (meer studente jaarliks as wat hul oorsese eweknieë ooit oor kon droom - of natgesweet van kon wakkerskrik) kan ons ons nou werklik op kwaliteit in die deeglike voorbereiding van baie minder studente toele. Hierin bly rekenaarsteun 'n belangrike hulpmiddel.4

\section{BIBLIOGRAFIE}

Blair R.W. (ed.) 1982. Inleiding: "Innovative approaches to language teaching". Newbury Publications, Rowling, Mass.

Boettcher, E.F., S.F. Alderson \& M. Sacucci 1981. "A comparison of the effects of computer-assisted instruction versus printed instruction on student learning in the cognitive categories of knowledge and application." ADCIS Journal 8(1):13-17.

Boshoff, C.J. 1989. "Kriteria en prosedures vir die evaluering van rekenaargesteunde onderrigprogrammatuur". S.A. Tydskrif vir Hoër Onderwys 3(2):115-21.

Braidi, S.M. 1988-1989. "Modern adventures in ancient Rome." Enquiry, Research at the University of Delaware, Newark DE.

British Council, The 1987. "Communicative language learning and the microcomputer."

British Council, The 1988. Central Information Service, ETIC "Bibliography no. 2: Computer - assisted language learning: an annotated bibliography."

Burkhardt, H., R. Frazer et al., geen datum. "Design and development of programs as teaching material. Council for Educational Technology on behalf of the Microelectronics Education Programme." London \& Newcastle.

Claassen, J.M. 1988. "Experiments in the teaching of introductory Latin at university level." SA Tydskrif vir Hoër Onderwys 2(1):35-40.

4 Navrae oor die aankoop of huur van die US-materiaal kan gerig word aan Dr. M.M. Malan, BUVO, Universiteit Stellenbosch, by (e-pos): MMM@maties.sun.ac.za. 
Claassen, J.M. 1989. "The use of the microcomputer in teaching Latin language and literature in a multilingual society." Per Linguam 5(1):33-41.

Claassen, J.M. 1991. "The design of computer software for computer-aided instruction in Latin". Per Linguam 7(1):3-24.

Claassen, J.M. 1993. "Computer programs for compulsory Latin." Learning Latin Newsletter 7:4-6.

Culley, G.R. 1972. "Computer-assisted instruction and Latin: beyond flashcards." Classical World 72(7):393-401.

Culley, G.R. 1989. "Liber: a tool for transition". Unpublished, Dept. of Foreign languages and literatures, Delaware University, Newark DE.

Emmanuelli, A.J. 1986. "Artificial intelligence and computer-assisted language learning". VEA Papers in Linguistics 25(6):43-56. Aangehaal in: Language Teaching 1987:324.

Hart, S. 1989. "What university students think of CALL in language courses." CALLBOARD 11.

Higgins, J. \& T. Johns 1984. "Computers in language learning." London: Collins.

Jones, C. \& S. Fortescue 1986. "Using computers in the language classroom." London: Longman.

Kerschenbaum, P. 1986. "SCIO." Classical World 79(5):319-322.

Kussler, R. 1989. "Literatuuronderrig deur middel van 'Hiperteks'." SA Tydskrif vir Taalonderrig 23(1):72-88.

Latousek, R.B. 1989. "Survey of Latin instructional software for the microcomputer." ACL Teaching Materials and Resource Center, Miami University, Oxford, Ohio.

Learning Latin Support Group 1987ff. Learning Latin Newsletter, (continually updated) School of Classics, University of Leeds, Leeds LS2 9JT.

Malan, C. 1988. "Rekenaarhulp as moontlike oplossing vir probleme wat eerstejaarstudente ondervind." Proceedings, Third annual conference and workshop on excellence in teaching and learning in higher education, Stellenbosch.

Murray, J.H., D. Morgenstern \& G. Furstenburg 1989. "The Athena language-learning project: design issues for the next generation of computer-based language learning tools.", in: Wm Flint Smith ed. Modern technology in FL education. National Textbook Co, Lincolnwood, Illinois.

Papert, S. 1980. Mind-storms. Brighton: Harvester.

Reeves, T.C. and R.M. Lent 1982. "Levels of evaluation for computer-based instruction." Paper presented at AGM of American Educational Research Association. Eric reports ED 217870.

Robinson, B. 1985. "Microcomputers and the language arts." Milton Keynes, Open University Press.

Rubenstein, J.G. 1987. "DISCO." Classical World 81(1):31-32. 


\section{Sagteware}

Cairns, F. \& M. Haywood 1988. Learning Latin Computer Package (LLCP). The School of Classics, University of Leeds, Leeds, LS2 9JT, Great Britain.

Claassen, D.M. \& J.M., met E. Zietsman \& S. Joubert, 1991. C.O.N.S.E.N.S.U.S. BUVO, Universiteit Stellenbosch.

Cambridge Latin Course 1989. Verskeie rekenaarprogramme. Cambridge Educational, CUP, The Edinburgh Building, Shaftesbury Road, Cambridge CB2 2RU.

Culley, G.R. et al. 1991. Liber. Newark, DE: University of Delaware. (Word tans ontwikkel.)

Culley, G.R. et al. 1984, 1987. Latin Skills. Newark, DE: University of Delaware, (5 programme: "Verb factory", "Mare nostrum", "Cursus honorum", "Translat", "Artifex verborum".)

Culley, G.R. et al. 1989. Castra Variana. Newark, DE: University of Delaware.

Culley, G.R. et al. 1989. Lector. Newark, DE: University of Delaware.

Kerschenbaum, P. \& A. Kerschenbaum. 1984. SCIO. New York, NY. Kerschenbaum, 60 Schriever Lane, New City, NY 10956.

Latousek, R.B. 1985, 1987. Latin flash drill; Latin vocab drill. Madison, WI: Centaur Systems.

Latousek, R.B. 1988. Tutrix. Madison, WI: Centaur Systems.

Malan, C.A. \& S. MacDonald, met E. Zietsman, N. Brand, V. Raubenheimer \& J.M. Claassen 1988-1990: PISCINA. BUVO, Universiteit Stellenbosch.

Rubenstein, J. 1984. DISCO. Rubenstein, 7394 Westmoreland Drive, St Louis, MO 63119. 